\title{
FOREST FIRE EFFECTS ON AIR QUALITY IN ONTARIO Evaluation of Several Recent Examples
}

\author{
by Frank Dempsey
}

Various remote-sensing, analysis, and forecasting methods allow anticipation of the harmful increases in airborne fine particulates and ozone pollution caused by the plumes of distant fires.

S

moke and emissions from forest fires may impact locations far downwind from the source, particularly downstream from high pressure ridges in upper-level northwesterly flow, and cause measurable effects on air quality monitoring and reporting networks. Impacts of wildfire emissions include formation of precursor compounds for ozone $\left(\mathrm{O}_{3}\right)$ and aerosol particles consisting of black and organic carbon as well as mineral ash. The precursor compounds may result in enhanced $\mathrm{O}_{3}$ formation over a large area downwind (e.g., Pfister et al. 2008). The emitted aerosol particles of all sizes may affect radiative properties, act as cloud condensation nuclei, and affect human activity such as by causing breathing and pulmonary difficulties (Nel 2005). A significant

AFFILIATION: DEMPSEY-Environmental Monitoring and Reporting Branch, Ontario Ministry of Environment, Etobicoke, Ontario, Canada CORRESPONDING AUTHOR: Frank Dempsey, 125 Resources Road, West Wing, Etobicoke, ON M9P 3V6, Canada E-mail: frank.dempsey@ontario.ca

The abstract for this article can be found in this issue, following the table of contents.

DOI:10.1175/BAMS-D-II-00202.I

A supplement to this article is available online (10.II75/BAMS-D-II-00202.2)

In final form 14 December 2012

(C)2013 American Meteorological Society example of downwind enhancement was the forest fires in Quebec in July 2002 [see the National Aeronautics and Space Administration (NASA) Visible Earth picture online at http://visibleearth .nasa.gov/view_rec.php?id=3339; image courtesy of NASA]. Plumes of smoke reaching Philadelphia were found to have concentrations of carbon monoxide (CO) and fine particulate matter that were enhanced by factors of between 5 and 10 while advecting southward above the boundary layer (Clark et al. 2003).

Significant chemical compounds emitted to the atmosphere by wildfires include $\mathrm{CO}$, carbon dioxide $\left(\mathrm{CO}_{2}\right)$, oxides of nitrogen $\left(\mathrm{NO}_{\mathrm{x}}\right)$, methane $\left(\mathrm{CH}_{4}\right)$, light hydrocarbons and polycyclic aromatic hydrocarbons (PAH), oxygenated volatile organic compounds (VOC), ammonia $\left(\mathrm{NH}_{3}\right)$, peroxides, chlorine and bromine compounds, and some sulfur compounds. Various stages of the combustion process cause varying production and emission rates of chemical species (Andraea and Merlet 2001). During the early stage of flaming combustion in a crown (or canopy) fire (with high temperatures), compounds with high oxidation states tend to be emitted, including $\mathrm{CO}_{2}$, $\mathrm{SO}_{2}$, and $\mathrm{NO}_{\mathrm{x}}$. Less oxidized compounds, such as $\mathrm{CH}_{4}$ and $\mathrm{N}_{2} \mathrm{O}$, are emitted during later smoldering stages (with cooler temperatures) (Wayne 2000; Cofer et al. 1989). In sunlight, the hydrocarbons are photochemically oxidized to various peroxides and aldehydes, and then to $\mathrm{CO}$. The $\mathrm{CO}$ is significant 
for detection by satellite remote sensing because it is created by the oxidation of hydrocarbons (emitted during the wildfire) by hydroxyl radicals $(\mathrm{OH})$. Although the $\mathrm{CO}$ eventually gets oxidized to $\mathrm{CO}_{2}$ by reaction with $\mathrm{OH}$, the $\mathrm{CO}$ is not highly reactive and has a sufficiently long lifetime to persist and act as a tracer of smoke plumes. An example of the significance of $\mathrm{CO}$ emissions from forest fires is the finding that $\mathrm{CO}$ concentrations in the southeastern United States were found to be significantly enhanced (along with increased concentrations of $\mathrm{O}_{3}, \mathrm{VOC}$, and aerosols) by emissions and long-range transport from large forest fires in Canada (Wotawa and Trainer 2000). Additionally, numerous compounds develop from the VOC- $\mathrm{NO}_{\mathrm{x}}$ chemistry in the plume (in sunlight), resulting in increasing concentrations of $\mathrm{O}_{3}$, and the increased $\mathrm{O}_{3}$ promotes generation of $\mathrm{OH}$ radicals. The increased $\mathrm{OH}$ concentrations result in an increase in the photochemical activity of air masses affected by the plumes from the burning biomass (Crutzen and Andreae 1990).

One result of the release of a large mass and variety of hydrocarbon compounds from wildfires is the production of secondary organic aerosols (SOA). Gas-to-particle conversion processes acting on emitted biogenic hydrocarbons and their oxidation products allow aerosol particles to form and then change in size and composition, and photochemical activity increases the oxidation of organic aerosols (Jimenez et al. 2009). While oxidation of VOCs may be the most significant mechanism for production of organic compounds with lower vapor pressures that tend to condense onto nuclei, other transformation mechanisms in the atmosphere include condensation or evaporation of vapor-phase compounds, coagulation with other particles, or activation and growth in the presence of water vapor (Kroll and Seinfeld 2008). The large number of solid-phase particles emitted by wildfires provides a significant source of condensation nuclei available for uptake and condensation of the organic compounds with low vapor pressure that tend to exist in the condensed phase. The result of the addition of secondary particles (formed in reactions) to primary particles (released directly to the atmosphere) is a rich and nonhomogeneous mixture of aerosol particles in plumes from wildfires.

Most of the wildfires that affect Ontario's air quality probably occur over western North America and atmospheric transport eventually advects the combustion products eastward. Analysis of geopotential height fields, winds, and vertical transport factors, along with data from remote sensing products that indicate location, depth, and movement of aerosol layers, and consideration of the close relation between meteorological factors and smoke transport and dispersion processes, allows forecasters to estimate the risk for smoke to affect large population centers.

Besides transport through the middle and occasionally upper levels of the troposphere, stratospheric injection and transport has been found to be possibly significant in the presence of fireaugmented pyrocumulus clouds that may develop from the heat released from large wildfires and may transport smoke and fire emissions to the upper troposphere or stratosphere (Fromm et al. 2010), and this transport method increases the number of major distant fires whose smoke plumes may affect eastern North America. While wildfires in western North America are a significant source of smoke for eastern North America, wildfires in Asia may also be an occasional source (Yu et al. 2008).

The recognition and forecasting of trajectories of smoke plumes from active fires would be beneficial for anticipating and predicting potential effects on air quality in eastern North America. The case study presented below for 17 June 2010 highlights a case where distinct increases in concentrations of fine particles and $\mathrm{O}_{3}$, closely correlated with the plume from a distant wildfire, were observed in routinely collected air quality observations in Ontario's air monitoring network. Several more examples have been presented in the supplementary online material (available online at http//:dx.doi.org//0.II75/BAMS -D-II-00202.2).

EXAMPLE OF 17 JUNE 20I0. Major lightninginitiated wildfires were burning in northern Saskatchewan during mid-June. During the first 2 weeks of June 2010, four wildfires larger than 100,000 ha were burning in northern Saskatchewan, and several more were larger than 10,000 ha in size. Two examples were the 10SR-Pasfield fire, reported to be burning over 453,144 ha from 4 June to 31 August and the 10SR-Ryan wildfire, burning over 191,315 ha from 9 June to 2 September [data are available at the Canadian Wildland Fire Information System (CWFIS) website; see http:// cwfis.cfs.nrcan.gc.ca/en_CA/datarequest/pntaccess /ba7e6d240I83c6134e3ab3c6868a57/e].

The fires in northern Saskatchewan were about $2,500 \mathrm{~km}$ from southern Ontario, and meteorological conditions were suitable for atmospheric transport of smoke plumes eastward across northern Ontario, and for downward transport to the surface. The smoke plume drifted southeastward over parts of southern Ontario and then coincided with sudden increases in 


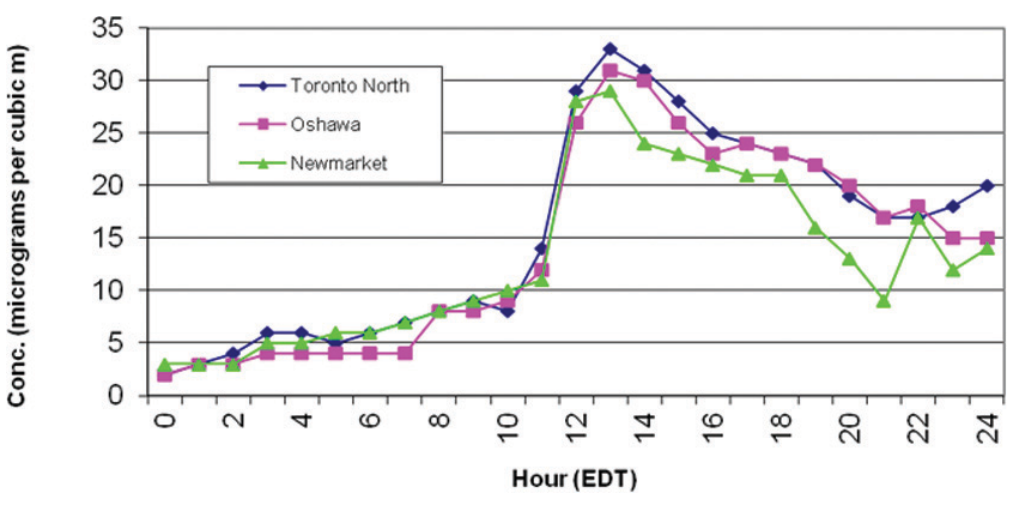

FIG. I. Concentrations of $\mathrm{PM}_{2.5}$ during 17 June 2010 for several locations in southern Ontario, indicating a sharp increase near noon. Measurements were made by the Tapered Element Oscillating Microbalance (TEOM) instrument at a temperature of $30^{\circ} \mathrm{C}$ with a Sample Equilibration System (SES). Errors are $<2 \mu \mathrm{g} \mathrm{m}^{-3}$.

concentrations of $\mathrm{PM}_{2.5}$ (particulate matter smaller than $2.5 \mu \mathrm{m}$ ) that persisted from mid-morning of 17 June until early morning of 18 June at some air quality monitoring stations of southern Ontario. The sudden increases in concentrations of $\mathrm{PM}_{2.5}$ coincided with northerly winds over southern Ontario.

The specific data that indicate detection of smoke from northern sources are the air quality observations from various locations in southern Ontario. The concentrations of $\mathrm{PM}_{2.5}$ increased sharply during 17 June at various air quality monitoring stations. Concentrations of $\mathrm{PM}_{2.5}$ measured at several stations (data available from the Ontario Ministry of the Environment air quality website; www .airqualityontario.com/history) are plotted in Fig. 1 for the Toronto North, Oshawa, and Newmarket air quality monitoring stations $(12 \mathrm{~km}$ north, $52 \mathrm{~km}$ northeast, and $45 \mathrm{~km}$ north of downtown Toronto, respectively). They indicate that concentrations increased significantly around noon. The time is coincident with the onset of convective mixing of the boundary layer, and is strongly indicative of a layer of pollutants above the boundary layer mixing downward to the surface. The chart in Fig. 1 plots the concentrations of $\mathrm{PM}_{2.5}$ for several stations north of Lake Ontario (for clarity), but a similar sharp increase in concentrations of $\mathrm{PM}_{2.5}$ was observed at the air quality stations in the general region of southern Ontario near western Lake Ontario. Observations at some other locations on this date include maximum 1-h $\mathrm{PM}_{2.5}$ concentrations of $26 \mu \mathrm{g} \mathrm{m}^{-3}$ at Peterborough $(111 \mathrm{~km}$ northeast of Toronto), $31 \mu \mathrm{g} \mathrm{m}^{-3}$ at Kitchener (92 km west of Toronto), $30 \mu \mathrm{g} \mathrm{m}^{-3}$ at Hamilton (59 $\mathrm{km}^{-3}$ southwest of Toronto), and $26 \mu \mathrm{g} \mathrm{m}^{-3}$ at St. Catharines ( $55 \mathrm{~km}$ south of Toronto).

The sharp and sudden increase was anomalous and conspicuous enough to attract attention by alert air quality forecasters. Generally, in similar meteorological conditions with northerly flow over southern Ontario ahead of a high pressure ridge, concentrations of $\mathrm{PM}_{2.5}$ decrease, particularly when wind speeds increase during late morning, and are generally less than the range of $10-15 \mu \mathrm{g} \mathrm{m}^{-3}$.

Another conspicuous observation was a significant increase in $\mathrm{O}_{3}$ concentrations, which increased at some locations to the range of $70-75 \mathrm{ppb}$, while remaining in the range of $45-50 \mathrm{ppb}$ at other locations. In Fig. 2, $\mathrm{O}_{3}$ concentrations are plotted for several stations, showing the higher concentrations at Hamilton and Burlington (59 and $51 \mathrm{~km}$ southwest of Toronto, respectively) and Toronto, but lower concentrations at Oshawa, Barrie (83 km north of Toronto), and Dorset (175 km northeast of Toronto). This was conspicuous because the meteorological conditions (sunny with winds from the north) were appropriate for a day when generally similar and consistent $\mathrm{O}_{3}$ concentrations would be expected at most or all of the air quality monitoring stations across southern

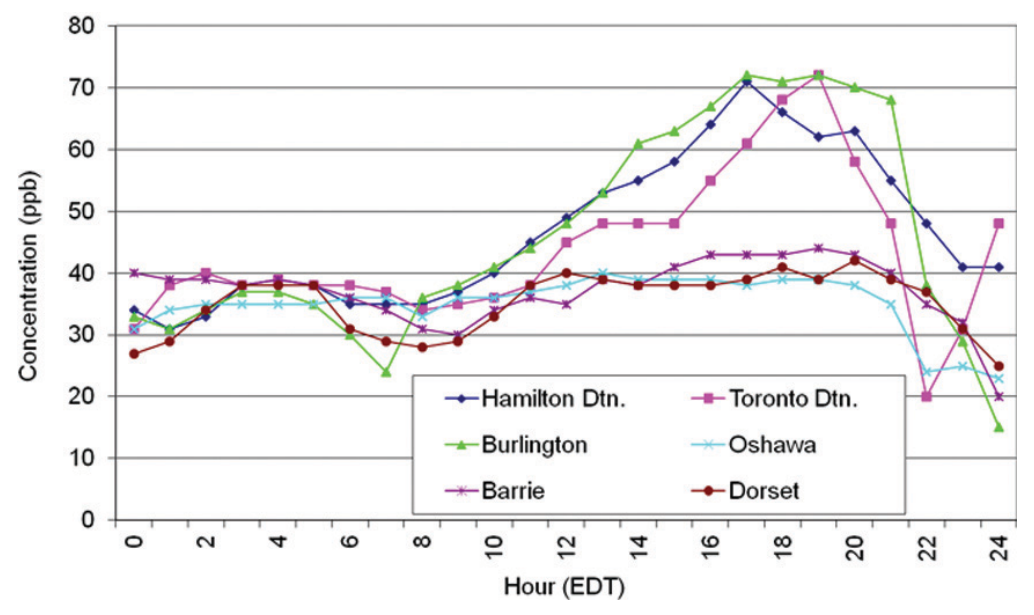

FIG. 2. Concentrations of $\mathrm{O}_{3}$ during 17 June 2010 for several locations in southern Ontario, showing significant increases in concentrations at some locations but background concentrations at other locations. Measurements were made by dual-cell UV photometric $\mathrm{O}_{3}$ analyzer. Errors are \pm I ppb. 


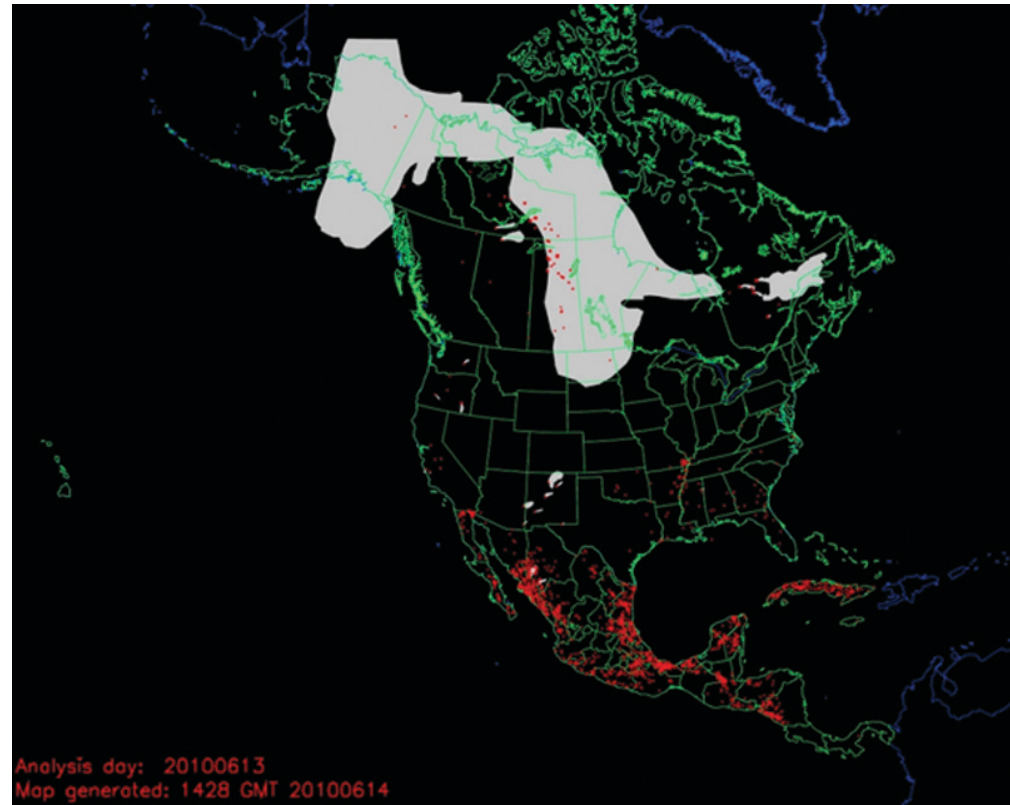

FIG. 3. HMS smoke analysis chart for 13 June 2010 showing a smoke plume developing southeast of wildfires in northern Saskatchewan and eastern Northwest Territories (courtesy of NOAA HMS; www .osdpd.noaa.gov/ml/land/hms.html). tions among the smoke pollutants in discrete plumes above the boundary layer that descended while advecting southward. The inhomogeneous regions of enhanced $\mathrm{O}_{3}$ then affected some locations and not others. These observations indicate that a layer of pollutants above the boundary layer (during the morning) at some locations mixed down to the surface and resulted in noticeably greater $\mathrm{O}_{3}$ concentrations than background concentrations that were observed at other stations (and expected at all of the monitoring stations during this synoptic meteorological situation).

Although a typical reason for lower $\mathrm{O}_{3}$ concentrations at some locations is cloudiness, especially along diurnal lake breeze fronts (Simpson 1994), skies were cloudless over southern Ontario during 17 June.

The source of the pollutants was

Ontario, including in the locations surrounding the Toronto region that are generally influenced by $\mathrm{O}_{3}$ produced photochemically (and that can be confidently predicted by forecasters). This was also significant because the meteorological situation of northerly winds on the east side of a high pressure ridge is normally associated with much lower $\mathrm{O}_{3}$ concentrations than when winds flow from the south, southwest, or west. Although not plotted in Fig. 2, some unexpectedly high $\mathrm{O}_{3}$ concentrations (1-min averages) that were recorded were $73 \mathrm{ppb}$ at the CN Tower air monitoring station (at a height of $444 \mathrm{~m}$ above ground level), $76 \mathrm{ppb}$ at Toronto Downtown, and $67 \mathrm{ppb}$ at Ryerson University (all in downtown Toronto). A possible cause of the noticeably higher $\mathrm{O}_{3}$ concentrations at the more southerly air quality stations was enhanced $\mathrm{O}_{3}$ production resulting from chemical reac-

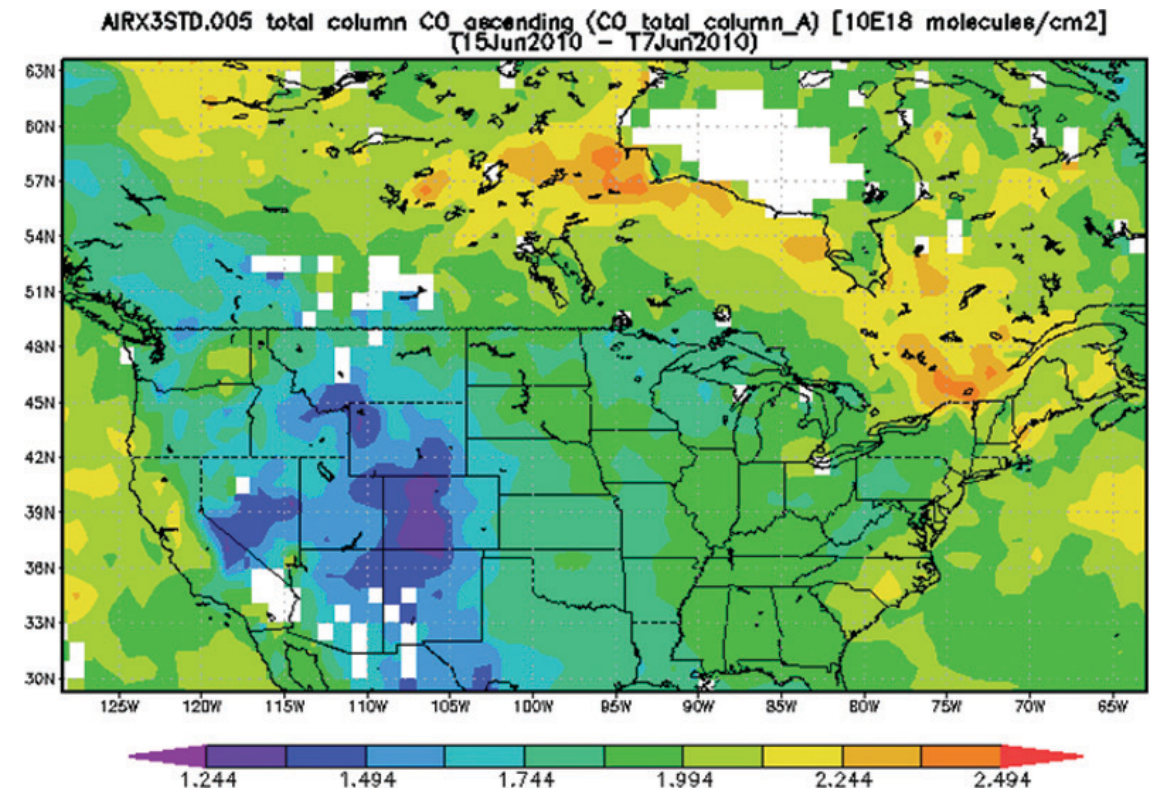

FIG. 4. Chart of CO column amount measured by AIRS over the period 15-I7 June 2010, showing the plume of CO-enriched air flowing southeastward from northern Saskatchewan (courtesy of NASA Giovanni; http://disc .sci.gsfc.nasa.gov/). most likely the wildfires in northern Saskatchewan that appear depicted on the National Oceanic and Atmospheric Administration (NOAA) Hazard Mapping System (HMS)-smoke analysis chart for 13 June in Fig. 3. The main feature relevant to Ontario 
is the plume of smoke extending southeastward from Northwest Territories, Saskatchewan, and Manitoba toward northern Ontario from the active fires plotted on the chart in northern Saskatchewan and eastern Northwest Territories. At the $700-\mathrm{hPa}$ level during the morning of 13 June the main features of the geopotential height pattern were a midlevel trough north of Quebec and a ridge south of Ontario, resulting in northwesterly flow from northern Saskatchewan to Ontario. A chart showing CO total column abundance, measured by the Atmospheric Infrared Sounder (AIRS) instrument on the NASA Aqua satellite, integrated over the period 15-17 June 2010 (Fig. 4) reveals a plume of $\mathrm{CO}$ extending southeastward from the northern prairies to northern Ontario. The regions with

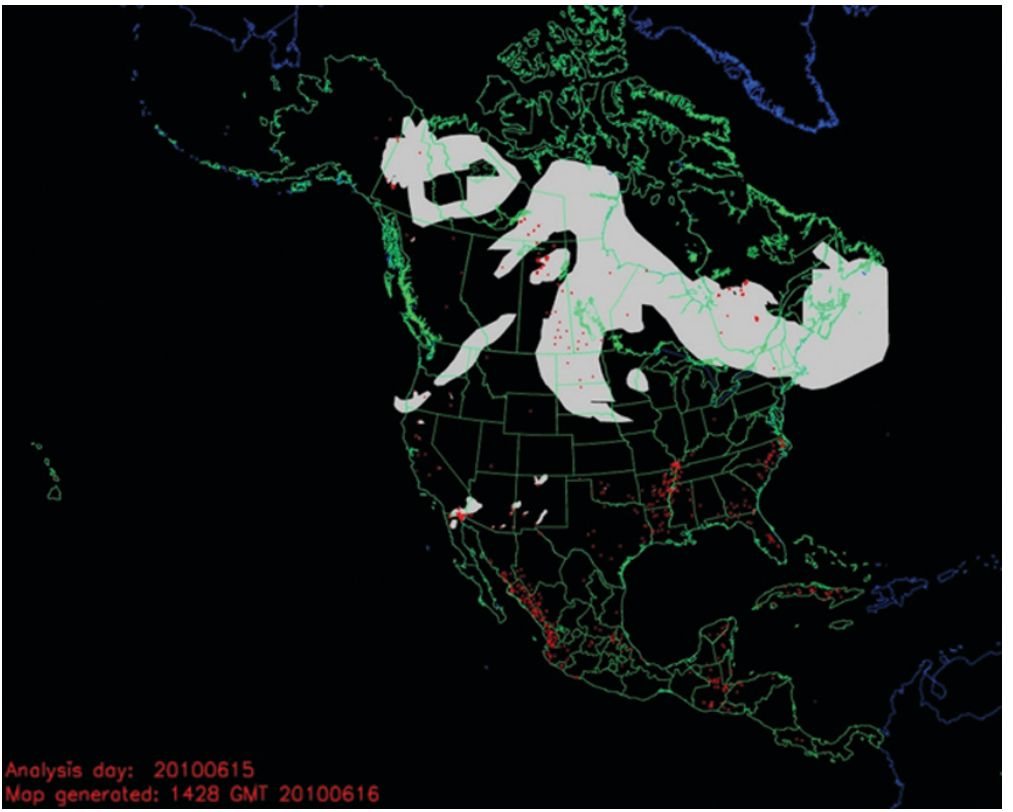

FIG. 5. HMS smoke analysis chart for 15 June 2010, showing the presence of the analyzed smoke plume over Ontario (courtesy of NOAA HMS; www.osdpd.noaa.gov/ml/land/hms.html).

column density greater than about $2 \times 10^{18}$ molecules per $\mathrm{cm}^{2}$ indicate a plume of $\mathrm{CO}$-enriched air extending from the region of active wildfires southeastward across Ontario, and generally coinciding with the direction along the gradient in $700-\mathrm{hPa}$ heights (between the trough north of Quebec and the ridge south of Ontario). The southeastward flow of smoke is also indicated in the HMS smoke analysis chart for 15 June in Fig. 5.

The dominant meteorological influence during 17 June was a high pressure ridge over the central Great Lakes region, which caused northerly winds and subsidence over southern Ontario. The subsidence provided ideal conditions for parcels of air (enriched with air pollutants) to convectively mix downward to the surface beginning in late morning, and downward motion of air parcels along isentropic surfaces east of the high pressure ridge contributed to downward movement of the pollutants to the surface. The main effect of the high pressure ridge on air quality in Ontario (besides causing the subsidence and northerly winds) was the low concentrations of both $\mathrm{O}_{3}$ and $\mathrm{PM}_{2.5}$ that are normally expected to be measured consistently across all of southern Ontario in this meteorological situation.

In summary of the example of 17 June 2010, a plume of smoke moved southeastward from Saskatchewan to northern Ontario and then southward over southern Ontario. The plume may have consisted of inhomogeneous regions of pollutants above the boundary layer that mixed downward to the surface during the daytime convection period and caused unexpectedly high concentrations of $\mathrm{PM}_{2.5}$ or $\mathrm{O}_{3}$ (or both) at some air quality monitoring stations in southern Ontario during 17 June. The presence of north to northwesterly winds across southern Ontario, and particularly Toronto, along with the conditions of $\mathrm{O}_{3}$ concentrations in the range of 45-50 ppb typically associated with northerly flow on the east side of high pressure ridges over the Great Lakes during summer, minimized the probability of the high $\mathrm{O}_{3}$ concentrations in downtown Toronto resulting from $\mathrm{O}_{3}$ formed photochemically in, or downwind of, a location associated with emissions of precursors such as the Toronto area.

Several more examples have been presented in the supplementary online material. In the example of 26 June 2010, a smoke plume that originated in northern Saskatchewan was transported southeastward to the Great Lakes region and caused abnormally high concentrations of $\mathrm{PM}_{2.5}$ at some of the air quality monitoring stations in southern Ontario. In the example of 27 July 2008, concentrations of $\mathrm{PM}_{2.5}$ increased rapidly at some of the air quality monitoring stations during late morning, following much lower concentrations during the morning. The smoke was most likely transported southeastward from wildfires that were burning in northern Saskatchewan and southern Northwest Territories several days earlier. 
SUMMARY. Evaluations of the examples used for this study (including in the supplementary online material) have pointed strongly to wildfires in central or western Canada as the sources of the smoke causing the increased concentrations of $\mathrm{O}_{3}$ and $\mathrm{PM}_{2.5}$ detected by air quality monitoring and reporting networks, such as in Ontario. The mechanisms of transport were found to be confidently identifiable by typical meteorological analysis and forecast methods including consideration of geopotential height patterns and winds, advective transport above the boundary layer, isentropic downglide of air parcels to lower altitudes within high pressure ridges, and convective vertical mixing through the boundary layer (during the appropriate diurnal periods).

Various remote sensing products and meteorological analysis tools that were found to be useful in diagnosis and transport of wildfire plumes include midlevel geopotential height analysis, CO total column amount, and Moderate Resolution Imaging Spectroradiometer (MODIS) visible imagery, as well as aerosol optical depth and back trajectory analysis plots (which have been used in the examples in the supplementary online material). Future improvements in remote sensing techniques that may be developed and implemented, such as increased satellite spatial resolutions and improvements in satellite retrieval validation (Martin 2008), will probably contribute to improving the accuracy of analysis and forecasting of wildfire effects on air quality in Ontario and large population centers in eastern North America.

ACKNOWLEDGMENTS. The author gratefully acknowledges helpful comments from Dr. Dave Yap and Dr. Robert Bloxam of the Ontario Ministry of Environment.

\section{REFERENCES}

Andraea, M., and P. Merlet, 2001: Emission of trace gases and aerosols from biomass burning. Global Biogeochem. Cycles, 15, 955-966.

Clark, R., C. Jeong, and C. Philbrick, 2003: The influence of Canadian wildfires on air quality in Philadelphia
PA during NE-OPS-DEP. Fifth Conf. on Atmospheric Chemistry, Long Beach, CA, Amer. Meteor. Soc., 6.4. [Available online at https://ams.confex.com/ams /pdfpapers/55639.pdf.]

Cofer, W., and Coauthors, 1989: Trace gas emissions from chaparral and boreal forest fires. J. Geophys. Res., 94, 2255-2259.

Crutzen, P., and M. Andreae, 1990: Biomass burning in the tropics: Impact on atmospheric chemistry and biogeochemical cycles. Science, 250, 1669-1678.

Finlayson-Pitts, B., and J. Pitts, 2000: Chemistry of the Upper and Lower Atmosphere: Theory, Experiments, and Applications. Academic Press, 969 pp.

Fromm, M., D. Lindsey, R. Servranckx, G. Yue, T. Trickl, R. Sica, P. Doucet, and S. Godin-Beekmann, 2010: The untold story of pyrocumulus. Bull. Amer. Meteor. Soc., 91, 1193-1209.

Jimenez, J., and Coauthors, 2009: Evolution of organic aerosols in the atmosphere. Science, 326, 1525-1529.

Kroll, J., and J. Seinfeld, 2008: Chemistry of secondary organic aerosol: Formation and evolution of low-volatility organics in the atmosphere. Atmos. Environ., 42, 3593-3624.

Martin, R., 2008: Satellite remote sensing of surface air quality. Atmos. Environ., 42, 7823-7843.

Nel, A., 2005: Air pollution-related illness: Effects of particles. Science, 308, 804-806.

Pfister, G., C. Wiedinmyer, and L. Emmons, 2008: Impacts of the fall 2007 California wildfires on surface ozone: Integrating local observations with global model simulations. Geophys. Res. Lett., 35, L19814, doi:10.1029/2008GL034747.

Simpson, J., 1994: Sea Breeze and Local Wind. Cambridge University Press, $248 \mathrm{pp}$.

Wayne, R., 2000: Chemistry of Atmospheres. 3rd ed. Oxford University Press, 775 pp.

Wotawa, G., and M. Trainer, 2000: The influence of Canadian forest fires on pollutant concentrations in the United States. Science, 288, 324-328.

Yu, H., L. Remer, M. Chin, H. Bian, R. Kleidman, and T. Diehl, 2008: A satellite-based assessment of transpacific transport of pollution aerosol. J. Geophys. Res., 113, D14S12, doi:10.1029/2007JD009349. 